\title{
OHIO WESLEYAN UNIVERSITY NATURAL RADIOCARBON MEASUREMENTS IV
}

\author{
J. GORDON OGDEN, III and RUTH J. HAY \\ Department of Botany and Bacteriology, \\ Ohio Wesleyan University, Delaware, Ohio
}

INTRODUCTION

The following list of dates is compiled from samples prepared since publication of our last date list (Radiocarbon, 1967, v. 9, p. 316-332) and includes determinations through June, 1968. Equipment and operating procedures are the same as described in OWU-III.

Unless noted otherwise, all samples are pre-treated with hot $2 \%$ $\mathrm{NaOH}$ and $10 \%$ HCl. Samples of archaeological charcoal are subjected to an additional pretreatment to remove rootlet cellulose following the method of Haynes (1966). Purity of sample $\mathrm{CO}_{2}$ and $\mathrm{CH}_{4}$ is checked with a gas chromatograph. Methane samples are stored for one month to permit decay of radon prior to counting.

Ages are quoted with a $l_{\sigma}$ counting error which includes the statistical variation of the sample count as well as that for background and for the contemporary standard. The half-life value is $5568 \mathrm{yr}$, and the reference year is 1950 .

\section{ACKNOWLEDGMENTS}

The support of the National Science Foundation (GB-3416) is gratefully acknowledged. Thanks are due to Professor George W. Burns for identification of wood samples described in this report.

\section{SAMPLE DESGRIPTIONS}

\section{Silver Lake, Ohio, Oak Tree series}

\section{GEOCHEMICAL SAMPLES}

Tree rings from large oak tree (Quercus alba L.) in grove of oak and hickory trees at Silver Lake, Ohio $\left(40^{\circ} 21^{\prime} \mathrm{N}\right.$ Lat, $83^{\circ} 48^{\prime} \mathrm{W}$ Long). These dates form part of an extensive study of vegetational and geochemical history of this lake and its vicinity (Ogden, 1966, 1967, see p.
138).

\section{GEOLOGIC SAMPLES}

\section{OWU-190. Akron Mastodon}

$15,315 \pm 625$

Spruce wood (id. G, W Burns) from beneath parta, 1365 B.C. mastodon excavated during building com Remains Remains were found in homogeneous lake clay with scattered organic math entrapment of mastodon in clay. Pollen in the clay is sparse and is principally spruce, pine, and sedge. Coll. and subm. by P. Wingard. Comment (J.G.O.): another piece of this $\log$ dated $13,300 \pm 600$ (M-1971). Although difference is within $2 \sigma$, additional material is available and sample will be rerun. 


\begin{tabular}{|c|c|}
\hline 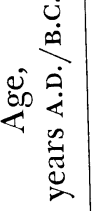 & 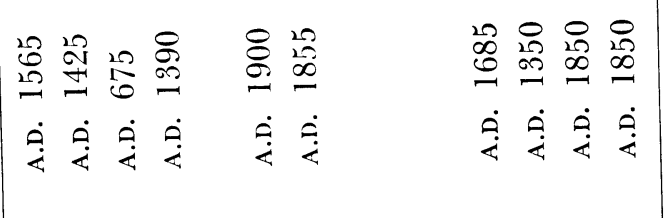 \\
\hline 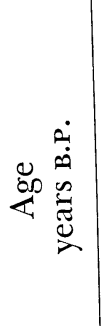 & 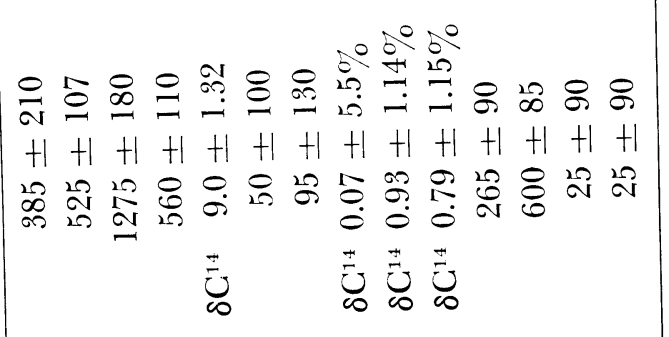 \\
\hline 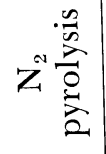 & $++++++1+1+1+1+$ \\
\hline$\vec{U}$ & ++++++++++++++ \\
\hline 䓠 & +++++++++++++ \\
\hline 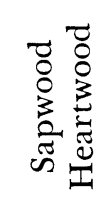 & 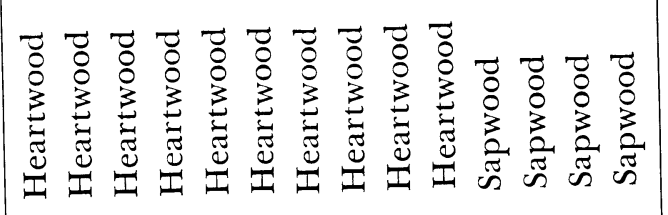 \\
\hline 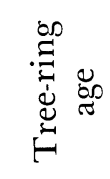 & 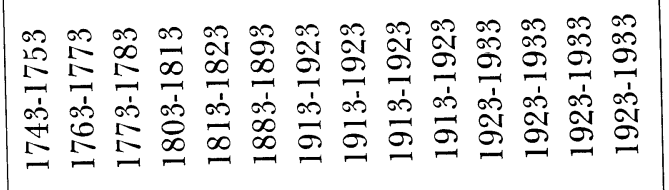 \\
\hline 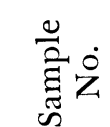 & 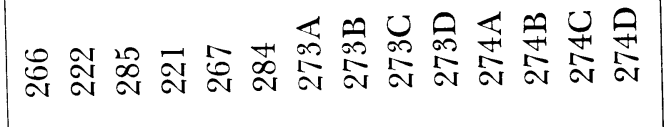 \\
\hline
\end{tabular}




\section{OWU-256. Fayette County, Ohio B-9}

$17,340 \pm 390$

15,390 B.C.

Black organic clayey silt with plant fragments from test boring for Interstate Bridge Fay-71-0205 under Twp. Rd. 83 (39॰ $36^{\prime}$ N Lat, $83^{\circ}$ $38^{\prime} \mathrm{W}$ Long). Core no. B-9c; S-2B, sample depth 45.9', absolute alt. 1007.8. Sample believed to be buried topsoil at surface of paleosol. Sample contains $0.8 \%$ calcite; $4.7 \%$ dolomite; $5.9 \% \mathrm{CaCO}_{3}$ equivalent; $13.5 \%$ organic carbon; $23.2 \%$ organic matter. Coll. and subm. by M. H. Moos. Comment: (see OWU-257).

\section{OWU-257. Fayette County, Ohio B-16}

$19,735 \pm 475$

Black organic clayey silt with

Interstate Bridger from test boring for 42" $42^{\prime \prime}$ N Lat, $83^{\circ} 33^{\prime} 2^{\prime \prime}$ W Long). Core no. B-16, S-10B, sample depth 40.8', absolute alt. 998.4'. Sample is buried topsoil overlying paleosol. Sample contains $0.5 \%$ calcite; $8.5 \%$ dolomite; $9.7 \% \mathrm{CaCO}_{3}$ equivalent; $15.9 \%$ organic carbon; $27.3 \%$ organic matter. Coll. and subm. by M. H. Moos. Comment (J.G.O.): pollen samples recovered from core slugs include Polygonum cf. amphibium, Cerastium cf. alpinum, Dryas-type, Saxifraga sect. oppositifolia, Thalictrum spp., Epilobium spp., and much grass and sedge pollen to NAP total of nearly $50 \%$, and implies a nearly treeless condition. Of the tree pollen, only spruce, pine, and ash contribute substantially to the tree-pollen totals. One sample contained $2.0 \%$ of fir pollen. Samples indicate a much more arctic environment than previously described for Ohio (Ogden, 1966).

\section{OWU-260A. Ross County Mastodon site} First half $\mathrm{CO}_{2}$.

\section{OWU-260B. Ross County Mastodon site} Second half $\mathrm{CO}_{2}$.

\section{OWU-260C. Ross County Mastodon site}

$12,835 \pm 275$ 10,885 B.c.

$12,685 \pm 244$ 10,735 в.c.

$13,695 \pm 520$

11,745 в.c.

Second sample burned (same log). Spruce wood from extensive marl deposit near Hallsville, Ross County, Ohio $\left(39^{\circ} 27^{\prime} \mathrm{N}\right.$ Lat, $85^{\circ} 50^{\prime} \mathrm{W}$ Long) which has yielded remains of several mastodons. An earlier sample (OWU-220) dated 13,180 \pm 520 (Radiocarbon, 1967, v. 9, p. 321). OWU$260 \mathrm{~A}$ and $\mathrm{B}$ were prepared to test for fractionation in freeze-thaw purification of $\mathrm{CO}_{2}$ and methane in sample preparation. Coll. and subm. by O. H. Prufer. Comment (J.G.O.): dates accord with previous determination and also show that no fractionation occurs during preparation. Particular interest attaches to samples from this area, since fluted points are found in abundance around the shores of extinct lake marked by marl deposit. None have been found assoc. with large mammals, however. 
Gymnosperm wood from 3.08 to $3.12 \mathrm{~m}$ in core $(1.17 \mathrm{~m}$ water depth) from Terwilliger's Pond, Put-in-Bay, South Bass Is., Lake Erie $\left(41^{\circ} 39^{\prime}\right.$ N Lat, $82^{\circ} 49^{\prime} \mathrm{W}$ Long). Coll Sept., 1967 by W. S. Benninghoff, A. Stevenson, and J. L. Forsyth; subm. by J. L. Forsyth. Comment (J.L.F.): lake level at alt. $571.13 \mathrm{ft}$. Sample believed to be from subaerial peat and to represent time when late post-glacial isostatically controlled rising lake level reached ca. $561 \mathrm{ft}$. In our many attempts to determine time and depth of late-glacial low-water level of Lake Erie and also rate of isostatic rise of lake level, this date is 1st concrete evidence: lake level was ca. $10 \mathrm{ft}$ lower 2500 yr ago. The date is acceptable. $\begin{array}{cc}\text { OW U-286. Brown's Creek, Butler County, Ohio } & \mathbf{1 8 , 4 0 0} \pm \mathbf{1 6 , 4 5 0} \text { в.c. } \\ \text { Spruce wood (id. by G. W. Burns) from } \log 11.0 \mathrm{ft} \text { from base of sec. }\end{array}$ $18,400 \pm 430$ in till exposed in S bluff of Brown's Creek valley in SE 1/4 Sec. 33, Madison Twp., Butler County, Ohio. Coll. and subm. by L. Struble. Comment (J.G.O.): date relates to arrival of late Wisconsin Miami glacial lobe near boundary of Wisconsin drift.

\section{Titusville, Pennsylvania series}

Peat from exposure in gravel pit $1.6 \mathrm{mi} \mathrm{S}$ of post office in Titusville, Pennsylvania, along Hwy 8 (41 $37^{\circ}$ N Lat, $79^{\circ} 39^{\prime} \mathrm{W}$ Long). Coll. and subm. by G. W. White.

OWU-315. Titusville Peat 1835

Oxidized peat $24^{\prime}$ below surface of gravel pit. Prior date was 39,900 $+4900,-2900$ yr (I-1845).

OWU.316. Titusville Peat

Peat $27^{\prime}$ below surface of gravel pit. Unpubl. Groningen date 40,450 $\pm 890 \mathrm{yr}$.

General Comment (G.W.W.): dates confirm previous determinations and show that Titusville till is late Altonian rather than Illinoian as previously inferred. For stratigraphic details see White and Totten (1965).

\section{OWU-317. Plant opal}

$\delta \mathbf{C}^{14}+\mathbf{6 . 6 7} \pm \mathbf{4 . 6 \%}$

Opal phytoliths extracted from surface horizon $(0$ to $18 \mathrm{~cm})$ of welldrained Brunizem soil (Warsaw silt loam, Site CH-34, Lab. no. 10539) from terrace along Mad R. Valley, W-central Ohio. Previous sample reported by Wilding (1967) had extensive pretreatment with chromic acid which reduced carbon content of opal phytoliths to $1.30 \%$ carbon and dated $13,300 \pm 450$ yr (I-2277). OWU-317 received only mild peroxide pretreatment and showed $4.75 \%$ Carbon (from original sample of $4.95 \%$ 
Ciarbon). Coll. and subm. by L. P. Wilding. Comment (L.P.W.): comparison of OWU-317 with I-2277 suggests extensive oxidation treatment is necessary to remove occluded contemporary carbon. A 3rd sample with intermediate oxidation pretreatment (2.97\% Carbon) is being prepared to test this possibility.

\section{Lake Erie series}

Core samples of detritus peat from 10 to $11^{\prime}$ below mud-water interface in 30 to $31^{\prime}$ of water found in several cores from near $S$ Bass Is. on $S$ side of Lake Erie ( $41^{\circ} 36^{\prime} \mathrm{N}$ Lat, $82^{\circ} 56^{\prime} \mathrm{W}$ Long). Samples presumed to represent land surface during lower lake level. Coll. 1967 by Ohio Geol. Survey and sub. by J. L. Forsyth.

\section{OWU-318. Station WR-31J}

Sample from $10.6^{\prime}$ below bottom in $30.4^{\prime}$ water. Pollen (J. G. Ogden) indicates strongly oxidized and fragmented detrital material, pine oak, and a few spruce grains with some grass and sedge pollen with poor preservation.

\section{OWU.319. Station WR-32J}

$9115 \pm 210$

Sample from $10.6^{\prime}$ below bottom in $30.5^{\prime}$ water. Pollen similar to OWU-318, but with slightly higher proportion of pine to oak. No significant difference in pollen spectra from the 2 sites.

General Comment (J.G.O.): wide discordance between dates indicates that organic layers do not represent former lake level, or more probably that wave action resulted in differential erosion and deposition. Additional core samples from same area will be analyzed to resolve the problem. If the latter interpretation is correct, then younger date will more closely approximate true age of flooding and eventual burial.

\section{GEOLOGIC SAMPLES-LAKE AND BOG SEDIMENTATION}

\section{Silver Lake series, Ohio}

This report continues studies on the paleoecology and geochemistry of Silver Lake (Radiocarbon, 1964, v. 6, p. 340-348; 1965, v. 7, p. 166-173; Ogden, 1966; 1967). The lake occurs in lime-rich clay till of central Ohio $\left(40^{\circ} 21^{\prime} \mathrm{N}\right.$ Lat, $83^{\circ} 48^{\prime} \mathrm{W}$ Long). The data are summarized in Table 1. Coll. 1966 and subm. by J. G. Ogden, III. Comment (J.G.O.): organic and marl carbon dates are highly variable in hard-water lakes. It would appear from these determinations that a sample error of at least \pm 500 yr must be assigned to radiocarbon dates from hard water lakes. The mean "Old Carbon" age of the surface sediments from this lake is 1200 yr, which has been subtracted from all long-core age determinations. Surface sample ages in this lake are also diminished by the amount of post-1950 bomb carbon in the sediments. Values as high as $+94 \%$ (OWU-107, reported in Radiocarbon, 1965, v. 7, p. 169) for contemporary 
rooted aquatic vegetation are recorded for this lake. The effects of bomb carbon are being studied further in short cores from soft water lakes. See Seth's Pond series in this paper and Ogden (1967). Although most of the marl determinations are older than the organic carbon ages, the only consistent pattern to be observed in these determinations is that there is apparently more "old" carbon in the post-Ambrosia rise sediments than earlier. This may be due to land clearance assoc. with the introduction of European agriculture in the early part of the 19th century.

\section{TABLE 1}

Radiocarbon Determinations from Short Cores at Silver Lake, Ohio

\begin{tabular}{lcccc}
\hline $\begin{array}{c}\text { Depth } \\
\text { cm. }\end{array}$ & $\begin{array}{c}\text { Sample } \\
\text { OWU- }\end{array}$ & $\begin{array}{c}\text { Core } \\
\text { no. }\end{array}$ & $\begin{array}{c}\text { Marl carbonate } \\
\text { age* }\end{array}$ & $\begin{array}{c}\text { Organic carbon } \\
\text { age }\end{array}$ \\
\hline $0-10$ & $73 * *$ & SL-2 & & $725 \pm 172$ \\
$10-20$ & $31 * *$ & SL-2 & & $820 \pm 84$ \\
$5-20$ & 268 & SL-3 & $1740 \pm 140$ & $1045 \pm 205$ \\
$5-20$ & 278 & SL-4 & $1305 \pm 80$ & $1030 \pm 130$ \\
$20-30$ & 269 & SL-3 & $1135 \pm 150$ & $920 \pm 140$ \\
$30-40$ & 279 & SL-4 & $485 \pm 235$ & $335 \pm 145$ \\
$40-50$ & 270 & SL-3 & $2260 \pm 180$ & $1145 \pm 200$ \\
$50-60$ & 226 & SL-3 & & $1288 \pm 167$ \\
$50-60$ & 280 & SL-4 & $2050 \pm 120$ & $1135 \pm 110$ \\
$60-70$ & $38 \dagger$ & SL-2 & & $1306 \pm 100$ \\
$60-70$ & 271 & SL-3 & $2170 \pm 175$ & $1570 \pm 165$ \\
$70-80$ & 227 & SL-3 & & $976 \pm 120$ \\
$70-80$ & 281 & SL-4 & $1145 \pm 110$ & $795 \pm 130$ \\
$75-85$ & 40 & SL-2 & & $1182 \pm 105$ \\
$80-90$ & 272 & SL-3 & $965 \pm 210$ & $880 \pm 150$ \\
$80-90$ & 282 & SL-4 & $640 \pm 130$ & $1255 \pm 100$ \\
$95-105$ & 41 & SL-2 & & $1753 \pm 189$ \\
\hline
\end{tabular}

* Where both organic carbon and marl carbonate ages are reported for a single laboratory number, the marl dates are identified by the letter " $\mathrm{A}$ " following the number; organic carbon dates by the letter "B".

** OWU I, p. $347,1964$.

† OWU II, p. 169, 1965. Rise in Ambrosia pollen occurs at 65 to $75 \mathrm{~cm}$.

\section{Seth's Pond, Massachusetts series}

These dates continue short-core radiocarbon and pollen studies in soft-water lakes previously reported (Radiocarbon, 1964, v. 6, p. 340-348; Ogden, 1967). There is no detectable limestone in till surrounding this lake, in a kettle $1 \mathrm{mi} \mathrm{E}$ of Lambert's Cove, Martha's Vineyard, Massachusetts (4118' N Lat, $70^{\circ} 46^{\prime} \mathrm{W}$ Long). 
OWU-123-bis. Seth's Pond, Massachusetts

$\delta \mathrm{C}^{14}+39.0 \pm 1.2 \%$

Re-run of OWU-123 from large surface sample $(0$ to $5 \mathrm{~cm})$ near center of pond in $4.50 \mathrm{~m}$ water. Value close to contemporary (1965 levels) vegetation OWU-127, Radiocarbon, 1965, v. 7, p. 171).

OWU.228A. Seth's Pond, Massachusetts $\delta \mathrm{C}^{14}+\mathbf{2 . 4 0} \pm \mathbf{1 . 8} \%$ Surface sample 5.1 from 0 to $5 \mathrm{~cm}$ in $4.85 \mathrm{~m}$ water.

OWU.228B. Seth's Pond, Massachusetts

$479 \pm 197$

Surface sample 5.1 from 0 to $5 \mathrm{~cm}$ in $4.85 \mathrm{~m}$ water. Sample OWU. $228 \mathrm{~A}$ from upper half of sect. 5.1. Slight stratigraphic distinction between upper and lower half of sample prompted division into $\mathrm{A}$ and $\mathrm{B}$ samples. Upper sect. friable on drying, yellowish brown, lower half dark homogeneous gyttja.

OWU-310. Seth's Pond, Massachusetts

Short core $(85 \mathrm{~cm}) 4.1$. Sample from 3 to $10 \mathrm{~cm}$ in gyttja.

$\delta \mathrm{C}^{14} \mathbf{5 . 0} \pm \mathbf{2 . 9 8 \%}$

OWU-312. Seth's Pond, Massachusetts

$375 \pm 135$

Sample from 50 to $60 \mathrm{~cm}$ (below Ambrosia rise) in A.D. 1575

General Comment (J.G.O.): this forms part of a series of studies contrasting sample variability in hard-water and soft-water lakes in Ohio and New England. (See Silver Lake series, this date list.) Although it appears that surface samples from soft-water lakes are as variable as hard-water lakes, (resolution $\pm 500 \mathrm{yr}$ ) the contemporary mud/water interface is unsuitable for reference dating due to post-1950 atomic bombproduced Carbon. An additional source of error is possible mixing with older sediments by bottom-burrowing organisms. Rise in Ambrosia pollen, a striking stratigraphic marker in NE N. America, at least removes the variability introduced by post-1950 bomb Carbon.

\section{Pretty Lake, Indiana series}

Extensive studies on the geology, hydrology, and physical limnology of Pretty Lake, Indiana (41 $35^{\prime} \mathrm{N}$ Lat, $85^{\circ} 15^{\prime} \mathrm{W}$ Long) are being conducted by the U. S. Geol. Survey in collaboration with Indiana University. Four-in. cores obtained by the U.S.G.S. have been analyzed for radiocarbon and pollen content. Core A, from which the following list of dates (Table 2) was obtained is $5.26 \mathrm{~m}$ long and was coll. in $28 \mathrm{~m}$ of water. The core consists of marly gyttja grading downward through clayey gyttja to clay. Core E, from a marl "island" has been sampled for radiocarbon and $\mathrm{C}^{12} / \mathrm{C}^{13}$ by the Yale Geochronmetric lab whose results will be reported elsewhere. Pollen analysis of all the cores is reported by Mrs. Alice S. Jones (Indiana Univ., Ph.D. dissertation, unpubl.). A comparison of radiocarbon and pollen stratigraphy of Pretty Lake and Silver Lake, Ohio is presented in Ogden (in press). Coll. U. S. Geological 
Survey and subm. by D. G. Frey and A. S. Jones. Comment (J.G.O.): the extraordinary correspondence between Pretty Lake and Silver Lake, Ohio, pollen records indicates that present vegetational differences between the 2 areas have existed for at least $10,000 \mathrm{yr}$ and that vegetational changes have been in phase and apparently synchronous. The Pretty Lake core bottomed in wood (OWU-242). All other dates include a correction of $-920 \mathrm{yr}$ (from surface sample, OWU-230) as estimate of Paleozoic carbonate contribution to the lake ecosystem. The close correspondence of corrected basal-gyttja date (OWU-241) with uncorrected wood date (OWU-242) confirms validity of core-sample correction by surface-sample determinations.

\section{TABle 2}

Radiocarbon Dates and Major Pollen Types from Core A, Pretty Lake, Indiana

\begin{tabular}{|c|c|c|c|c|}
\hline $\begin{array}{c}\text { OWU } \\
\text { Sample } \\
\text { no. }\end{array}$ & $\begin{array}{l}\text { Depth } \\
\text { cm }\end{array}$ & Major Pollen Types & $\begin{array}{l}\text { Radiocarbon } \\
\text { age }\end{array}$ & A.D./B.C. \\
\hline 230 & $0-6$ & oak-hickory-beech-Ambrosia & $920 \pm 210^{*}$ & \\
\hline 231 & $51-56$ & oak-hickory-beech & $720 \pm 160$ & A.D. 1230 \\
\hline 232 & $101-107$ & oak-hickory-beech & $1830 \pm 270$ & A.D. 120 \\
\hline 262 & $125-130$ & oak-hickory & $2695 \pm 320$ & 745 в.с. \\
\hline 233 & $145-150$ & oak-hickory & $3585 \pm 290$ & 1635 в.C. \\
\hline 263 & $181-186$ & oak-hickory & $3865 \pm 360$ & 1915 в.C. \\
\hline 234 & 201-206 & oak-hickory-beech & $3820 \pm 305$ & 1870 B.C. \\
\hline 235 & $251-256$ & oak-hickory-beech & $4340 \pm 305$ & 2390 B.C. \\
\hline 236 & $301-306$ & oak-hickory-beech-elm & $5885 \pm 340$ & 3935 в.c. \\
\hline 237 & $351-356$ & oak-hickory-pine-elm & $7495 \pm 205$ & 5545 в.c. \\
\hline 264 & $381-386$ & pine-elm & $9295 \pm 345$ & 7345 B.c. \\
\hline 238 & 401-406 & spruce-pine-oak & $10,195 \pm 215$ & 8245 в.c. \\
\hline 239 & $425-430$ & spruce-oak & $10,860 \pm 270$ & 8910 в.C. \\
\hline 240 & $451-456$ & spruce & $11,750 \pm 270$ & 9800 в.c. \\
\hline 241 & $501-506$ & spruce & $13,375 \pm 610$ & 11,425 в.с. \\
\hline $242 * *$ & $520-525$ & spruce & $13,265 \pm 520$ & 11,315 в.с. \\
\hline
\end{tabular}

* All core dates corrected for Paleozoic carbonate by subtracting 920 years from the raw radiocarbon date except OWU-242.

** Date determined on spruce wood at bottom of core and therefore not corrected for paleozoic carbonate.

\section{Brown's Lake Bog series}

As part of series of studies of late-glacial and post-glacial history of Ohio, a core $3 \mathrm{~cm}$ in diameter and $13.7 \mathrm{~m}$ long was recovered with a Livingstone piston sampler from Brown's Lake Bog $\left(40^{\circ} 41^{\prime} \mathrm{N} \mathrm{Lat}, 82^{\circ} 3^{\prime}\right.$ W Long), in a kettle ca. $2 \mathrm{mi} \mathrm{W}$ of Shreve, Ohio; report to be published elsewhere. Table 3 lists dates and major pollen components of the core. 
Coll. 1967 and subm. by J. G. Ogden, III. Comment (J.G.O.): Brown's Lake Bog profile contains a single beech-pollen maximum, between the 2 beech maxima recognized from Silver Lake, Ohio and Pretty Lake, Indiana (Ogden, in press). Further studies on similar bogs in NW Ohio will resolve whether difference in pollen records reflects edaphic differences between lake and bog records or whether vegetational boundary limiting the distribution of beech existed throughout central Ohio ca. 3000 yr ago.

\section{TABle 3}

Radiocarbon Dates and Major Pollen Types for Core BLBG-1, Brown's Lake Bog, Wayne County, Ohio

\begin{tabular}{cclcc}
\hline $\begin{array}{c}\text { OWU } \\
\begin{array}{c}\text { Sample } \\
\text { no. }\end{array}\end{array}$ & $\begin{array}{c}\text { Depth } \\
\mathrm{cm}\end{array}$ & Major Pollen Types & $\begin{array}{c}\text { Radiocarbon } \\
\text { age }\end{array}$ & A.D. $/$ B.c. \\
\hline 289 & $95-100$ & Oak-hickory-Ambrosia & $565 \pm 105$ & A.D. 1385 \\
291 & $295-300$ & Oak-hickory & $1185 \pm 100$ & A.D. 765 \\
292 & $395-400$ & Oak-beech-hickory & $1910 \pm 170$ & A.D. 40 \\
293 & $495-500$ & Oak-sedge-pine-beech & $3145 \pm 165$ & 1195 B.C. \\
295 & $695-700$ & Oak-beech-hickory & $4210 \pm 145$ & 2260 B.c. \\
297 & $895-905$ & Oak-pine-elm & $8030 \pm 185$ & 6080 B.c. \\
299 & $1020-1030$ & Oak-pine-elm & $8700 \pm 175$ & 6750 B.c. \\
300 & $1070-1080$ & Pine-oak & $9670 \pm 190$ & 7720 B.C. \\
302 & $1160-1170$ & Pine-spruce-oak & $10,915 \pm 205$ & 8965 B.c. \\
303 & $1180-1190$ & Spruce-pine-oak & $9305 \pm 355$ & 7355 B.c. \\
304 & $1200-1210$ & Spruce-pine-oak & $10,595 \pm 370$ & 8645 в.C. \\
\hline
\end{tabular}

\section{ARCHAEOLOGIC SAMPLES}

\section{O.C. Voss site-1966 series}

The following determinations are part of a continuing series of investigations by the Ohio Historical Soc. into the Mound City Group Natl. Monument (39॰22' N Lat, $83^{\circ} 0^{\prime} \mathrm{W}$ Long). All samples are wood charcoal and all but OWU-244 have been pretreated for removal of rootlet cellulose by the method of Haynes (1966). Coll. 1966 by R. S. Baby and M. Potter and subm. by R. S. Baby.

\section{OWU-229A. Square 190L12 Upper sample}

OWU-229B. Square 190L12 Lower sample

Sample divided into upper and lower portions because of suspicion of intrusive material in top of sample. Material was wood charcoal, probably ash or hickory (id. by G. W. Burns) in a midden area.

$$
\begin{array}{r}
\delta C^{14} 3.6 \pm 1.20 \% \\
1040 \pm 215
\end{array}
$$

\section{A.D. 910}


OWU-243A. Refuse pit. Feature IX

OWU-243B. Refuse pit. Feature IX

A.D. 1135

Sample divided as in OWU-229 above. Sample consisted of oak charcoal with black walnut shell. Refuse pit contained 1 burial (fetus).

OWU-244. Post-hole (\#87-9) Feature XI, House II

$675 \pm 90$

A.D. 1275

Sample was quite small and showed no evidence under microscope of rootlet contamination. Pretreated with $\mathrm{NaOH}$ and $\mathrm{HCl}$ only.

OWU.245. Feature XIX

$$
517 \pm 110
$$

Wood charcoal of Feature XIX assoc. with House II. Feature XVIII.

\section{OWU.246. Feature XX}

A.D. 1563

$387 \pm 158$

Wood charcoal assoc. with House II. Feature VXIII.

General Comment (R.S.B.): OWU-229B, 243B and 244 are compatible with OWU-92A (Radiocarbon, 1965, v. 7, p. 172) which showed $970 \pm$ $79 \mathrm{yr}$. Samples from plaza or ceremonial center of Cole Complex. OWU245 and -246 represent intrusion of later refuse pits into post mold pattern of House II, Features XIX and XX. Later occupation is also reflected in late Cole complex ceramics included with these samples. Contemporary age of OWU-229A and 243A confirm field suspicion of late intrusion.

\section{Blain's Village series}

Baum focus Fort Ancient site near Chillicothe, Ross County, Ohio (39॰ $19^{\prime} \mathrm{N}$ Lat, $82^{\circ} 56^{\prime} \mathrm{W}$ Long). Samples consisted of charred corn and charcoal. In OWU-247 A, corn kernel charcoal was hand-picked to constitute a sample. Most of the corn charcoal was removed from OWU247B. Coll. and subm. by O. H. Prufer.

\section{OWU.247A. Pit 4}

$405 \pm 150$

Sample consisted of pure corn kernel charcoal.

$$
970 \pm 220
$$

OWU-247B. Pit 4

Sample mostly wood charcoal from sealed primary refuse pit 20 to $24^{\prime \prime}$ deep.

\section{OWU-248. Pit 2}

$1035 \pm 155$

Sample of oak charcoal at depth 8 to $12^{\prime \prime}$ in Pit 2. A.D. 915

General Comment (O.H.P.): OWU-247A is too late, presumably due to anomalous fractionation by corn. Dates for OWU-247B and OWU-248 
are acceptable. Marks earliest Fort Ancient (Baum focus) manifestation in Ohio. Interestingly, pit contained Woodland vessel in addition to Fort Ancient materials.

Laboratory Comment (J.G.O.): if date for OWU-247A is normalized for anomalous Carbon isotope chemistry $(-11.2 \%)$, radiocarbon age becomes $645 \pm 150$ yr B.P. or more nearly in line with other dates.

\title{
OWU-249. Stanhope Cave, Jackon $2120 \pm \mathbf{2 4 0}$ \\ 179 B.C.
}

site near Jackson, Ohio (39 $13-3 / \mathrm{F} 2,10$ to $14^{\prime \prime}$ of Woodland by $\mathrm{O}$. H. Prufer. Como (39 $7^{\prime} \mathrm{N}$ Lat, $83^{\circ} 45^{\prime} \mathrm{W}$ Long). Coll. and subm. Assoc. cultural remains ant (O.H.P.): date is completely unacceptable. sample gave 1205 are late middle/early late Woodland. A similar $05 \pm 85$ (GX-966) which is acceptable. Culturally, level from which both samples were taken represents Peters phase of Scioto tradition.

\section{OWU-250. Leimbach site, Lorain County, Ohio}

$2460 \pm 260$

lant occupar . Coltion site near Brownhelm, Ohio (41 $22^{\prime} \mathrm{N}$ Lat, $82^{\circ} 20^{\prime} \mathrm{W}$ Long). Coll. and subm. by O. C. Shane, III.

\section{OWU-251. Leimbach site, Lorain County, Ohio $1935 \pm 240$}

A.D. 15

it Coll and are are acceptable and consistent with OWU-185 which gave $2470 \pm 309$ (Radiocarbon, 1967, v. 9, p. 330). Material dates early Woodland occupation closely related to Adena phase of Scioto tradition. Further details may be found in Prufer and McKenzie (1967).

\section{OWU.252. Rais Rock shelter, Jackson County, Ohio \\ $1555 \pm 155$ \\ A.D. 395}

Gymnosperm charcoal from Unit E-3, 10 to $12^{\prime}$ below floor of Woodland occupation site near Jackson, Ohio (39॰ $7^{\prime} \mathrm{N}$ Lat, $82^{\circ} 45^{\prime} \mathrm{W}$ Long). Coll. and subm. by O. C. Shane, III. Comment (O.C.S.): acceptable date for Hopewellian related level of Middle Woodland period.

OWU-253. Gabriel site, Athens County, Ohio

$425 \pm 155$

Wood charcoal (ash or chestnut, id. by G. W. Burns) from sealed deposit in pit at Gabriel site near Dover, Ohio $\left(39^{\circ} 23^{\prime} \mathrm{N}\right.$ Lat, $82^{\circ} 9^{\prime}$ W Long). Coll. and subm. by J. L. Murphy.

OWU.258. Wheelabout Rock shelter, Vinton County, Ohio

$\mathbf{7 7 0} \pm 215$

\author{
A.D. 1180
}

Wood charcoal from Sq. 2-B, Sample 1, 15' of Late Woodland occupation site (39॰ $15^{\prime} \mathrm{N}$ Lat, $82^{\circ} 22^{\prime} \mathrm{W}$ Long). Coll. and subm. by D. H. McKenzie. Comment (D.H.M.): dates Late Woodland (Chesser phase) occu- 
pation. This is not significantly different from A.D. $1070 \pm 140$ (OWU180) date obtained for this phase as Chesser Cave (Radiocarbon, 1967, v. 9 , p. 329).

OWU-259. Wheelabout Rock shelter, Vinton County, Ohio

$4570 \pm 240$

2620 B.C.

Charcoal from circular "pocket" of Sq. 3-B, Sample 2, 36 to 39" of site of OWU-258. Coll. and subm. by D. H. McKenzie. Comment (D.H.M.): this sample was obtained from lowest level of shelter, and dates small Archaic occupation immediately about sterile sand and rock. There would appear to be a generally Laurentian affiliation. The Archaic occupation is not clearly separated stratigraphically from Woodland occupation above.

\section{OWU-265. Seaman's Fort site, Erie County, Ohio $\quad \begin{array}{ll}2955 \pm 290 & 1005 \text { в.c. }\end{array}$}

Ring-porous angiosperm (ash or hickory) charcoal from Feature 5. Sample was quite small and diluted with "dead" methane to bring sample to optimum counter pressure. Sample should date Leimbach phase component, са. 500 to 100 в.c. Site located at $41^{\circ} 17^{\prime} \mathrm{N}$ Lat, $82^{\circ} 39^{\prime} \mathrm{W}$ Long. Coll. by R. C. Vietzen and subm. by O. C. Shane, III. Comment (O.C.S.): date is possible, but in light of other dates on similar assemblages, seems to be too early.

OWU-276. Enos Holmes mound,

\section{Highland County, Ohio}

$815 \pm 95$

Mixed wood charcoal, mostly oak and hickory from midden deposit on primary mound, Sq. 50, probably representing burned house structure. Sample location $39^{\circ} 14^{\prime} \mathrm{N}$ Lat, $83^{\circ} 22^{\prime} \mathrm{W}$ Long. Coll. and subm. by R. S. Baby. Comment (R.S.B.): date is well within range of Cole complex (late Woodland) and indicates emergence of Mississippian temple-mound building concepts in Ohio.

\section{REFERENCES}

Date lists:

OWU I

Ogden and Hay, 1964

OW

Ogden and Hay, 1965

OWU III

Ogden and Hay, 1967

Haynes, C. Vance, Jr., 1966, Radiocarbon samples: chemical removal of plant contaminants: Science, v. 151, p. 1391-1392.

Ogden, J. G., III, 1966, Forest History of Ohio I: radiocarbon dates and pollen stratigraphy of Silver Lake, Logan County, Ohio: Ohio Jour. Sci., v. 66, p. 387-400. 1967 Radion hard and soft-water lakes in northeastern North America, in Cushing, E. H. and Wright, H. E., Jr. (eds) Quaternary Paleoecology, Proc. VII INQUA Congress, v. 7, p. H. E., 175 - 183 .

(in press) Correlation of contemporary and late Pleistocene pollen records in the reconstruction of postglacial environments in northeastern North America: in the recont. Symposium on Paleolimnology, Tihany, Hungary, August, 1967.

Ogden, J. G., III and Hay, R. J., 1964, Ohio Wesleyan University natural radiocarbon measurements I: Radiocarbon, v. 6, p. 340-348. 
Ogden, J. G., III and Hay, R. J., 1965, Ohio Wesleyan University natural radiocarbon measurements II: Radiocarbon, v. 7, p. 166-173. carbon, v. 9, p. 316-332.

Prufer, O. H. and McKenzie, D. H., 1967, Studies in Ohio Archaeology, Western
Reserve Univ Press.

White, G. W.

called "Inner Illinoian"), northwestern Pennsylyania.

Wilding, L. P., 1967, Radiocarbon dating Pennsylvania: Science, v. 148, p. 234-235. 